\author{
Leszek Mrozewicz \\ (Poznań-Gniezno) \\ https://orcid.org/0000-0002-4670-1959
}

\title{
NA ZIEMI MATTIAKÓW
}

Anne Wieland, Civitas Mattiacorum. Forschungen zur römerzeitlichen Besiedlung im Wiesbadener Raum, Kölner Studien zur Archäologie der römischen Provinzen, 13, Verlag Marie Leidorf GmbH, Rahden/Westf., 2018, ss. 383, w tekście liczne ilustracje czarno-białe

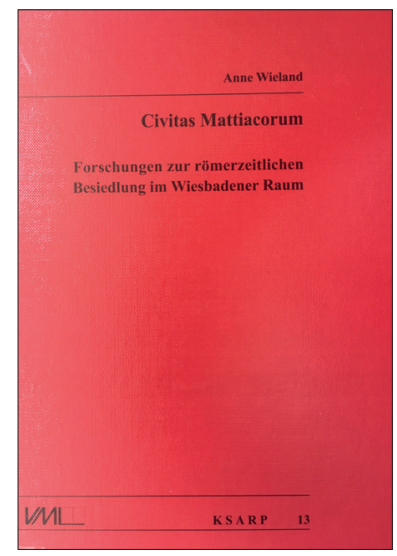

Cywilna organizacja prawobrzeżnej rzymskiej prowincji Germanii Górnej (tzw. agri decumates) stanowiła swoisty fenomen. Jej rdzeń tworzyły civitates (w liczbie 8-9), które z reguły w innych rejonach państwa rzymskiego wywodziły się w prostej linii z wcześniejszych, jeszcze przedrzymskich, struktur plemiennych. Tutaj natomiast miały one charakter całkowicie sztuczny, utworzone zostały - piszę to oczywiście z pewną przesadą - na surowym korzeniu, z założenia od razu jako jednostki administracji lokalnej. Nie były więc kontynuacją wcześniejszych struktur i tradycji. Plemiona, nazwami których je określono, były nimi tylko nominalnie, gdyż zasadniczy zrąb mieszkańców tworzyli przybysze, często nawet z odległych części Imperium Romanum. Oczywiście ogromny wpływ na rozwój i funkcjonowanie civitates miał limes, granica rzymsko-germańska (tzw. limes germańsko-retycki), ciągnąca się na długości blisko 500 $\mathrm{km}, \mathrm{z}$ dużą koncentracją wojsk zarówno na jej linii (auxilia), jak i nad Renem (legiony w Mogontiacum i Argentorate). Jak ważne jest badanie owych lokalnych społeczności i ich struktur organizacyjnych dla zrozumienia istoty państwa rzymskiego w ogóle, nie trzeba nikogo przekonywać. Zresztą lawinowy przyrost publi- 
kacji jest tego najlepszym dowodem. Mimo to kompleksowe opracowanie całości zagadnienia, to jest znaczenia zareńskich civitates, ich fenomenu, pozostaje otwartym wyzwaniem badawczym. Dlatego każda publikacja stanowiąca efekt szczegółowych badań nad konkretną civitas spotyka się z żywym odzewem.

Prezentowana książka dotyczy civitas Mattiacorum. Jej granica biegła w dół Renu, poczynając mniej więcej od Mogontiacum (dz. Moguncja, Mainz), na północy dochodząc do rzeki Lahn i opierając się o grzbiet Taunusu, a na wschodzie stykała się z civitas Taunensium. Natomiast południowy zasięg wyznaczała linia Renu i Menu. Nazwa civitas wzięła się od plemienia Mattiaków (Mattiaci), które wchodziło w skład większego zespołu plemiennego - Chattów (Chatti). Mattiakowie osiedleni tu zostali jeszcze przez cesarza Augusta, ale w chwili powstawania civitas (w okresie Trajana, który stworzył strukturę organizacyjną agri decumates) zapewne nie stanowili już zbyt licznej grupy mieszkańców. Centrum terytorialno-administracyjnym civitas stał się vicus Aquae Mattiacorum, czyli dzisiejszy Wiesbaden. Nazwę zawdzięczał on wodom termalnym (wykorzystywanym do dzisiaj), którym już w starożytności przypisywano właściwości lecznicze (zob. Plinius Maior, NH XXXI 20).

Książka dzieli się na dwie części. Pierwszą (s. 9-71) nazwijmy teoretyczną, bo stanowi ona tak naprawdę wprowadzenie do katalogu, który z kolei zawiera zestawienie i krytyczne omówienie wszystkich miejsc znalezienia (w tym stanowisk archeologicznych) różnego rodzaju pozostałości związanych z rzymską przeszłością civitas („Katalog der Fundstellen aus Hessen und Rheinland-Pfalz”, s. 73-383). Autorka słusznie przypisuje katalogowi znaczenie zasadnicze; w jej ocenie stanowi on już teraz pozycję bazową (Standardwerk) do dalszych badań. Zostały w nim zawarte i przeanalizowane

wszystkie dotąd znane materiały. Celem analizy było stworzenie możliwie całościowego obrazu zasiedlenia civitas Mattiacorum. Poprzez zestawienie wszystkich informacji odnośnie do dotychczas znanych miejsc pochodzenia różnych zabytków, sporządzenie planów i map ich rozprzestrzenienia, powinno się uzyskać odpowiedź na pytania dotyczące najwcześniejszych faz osadnictwa rzymskiego, przetrwania ludności miejscowej, przebiegu romanizacji, gęstości zaludnienia, specyfiki budownictwa, czasu trwania zasiedlenia, upadku panowania rzymskiego (...), jak też ludności jako takiej i stylu jej życia (s. 9).

Oczywiście to czytelnik, zapoznając się zestawionym materiałem, sam sobie na te pytania powinien odpowiedzieć. Niemniej przyznać trzeba, że katalog zestawiony został nadzwyczaj rozsądnie, w sposób dobrze przemyślany. Czytelnik znajdzie za każdym razem, w tej samej kolejności: nazwę miejscowości, nazwy rzek, dane topograficzne, historię badań danego miejsca, wskazówki bibliograficzne dotyczące konkretnego stanowiska, informację o miejscu przechowywania znalezisk, opis badań, opis znalezisk, datowanie, komentarz. Ten ostatni jest niezwykle ważny, 
zawiera zarówno ocenę osiągniętych wyników, jak i wskazań (perspektywy) co do dalszych ewentualnych badań. Stanowiska uporządkowane zostały w następującej kolejności geograficzno-administracyjnej: powiat Main-Taunus (Hesja), powiat miejski Wiesbaden (Hesja), powiat Rheingau-Taunus (Hesja) oraz powiat Rhein-Lahn (Nadrenia-Palatynat). Nie ma wątpliwości, że katalog stanowi niepodważalny punkt wyjścia do dalszych poszukiwań i w tym sensie służył będzie co najmniej kilku pokoleniom. Stanowi najważniejszą i zarazem najwartościowszą część pracy.

Nie można tego samego powiedzieć o części pierwszej (s. 9-71). Czytelnik znajdzie tu zarys historii oraz stanu aktualnego badań (s. 13-20) i dziejów civitas Mattiacorum (s. 21-27). Niestety, opracowanie to jest niezwykle zwięzłe, bez głębszego „zanurzania” się w istotę rzeczy. Na s. 28-37 scharakteryzowane zostały uwarunkowania geograficzne, klimatyczne i topograficzne regionu („Die Landschaftsräume in der civitas Mattiacorum"), według wskazanego już podziału administracyjnego, oraz szlaki komunikacyjne (drogi). Kolejny rozdział (s. 38-41) to sumaryczne zaprezentowanie miejsc znajdowania zabytków (Fundstellen), z jednoczesnym zwróceniem uwagi na trudności związane $\mathrm{z}$ datowaniem znalezisk. Niezbyt naukowo brzmi deklaracja autorki (s. 40), że kierowała się będzie w tym względzie autorytetem swych doświadczonych poprzedników. Rozczarowują rozdziały zarówno o zasiedleniu civitas Mattiacorum („Die Besiedlung der civitas Mattiacorum”, s. 42-45), jak i o „życiu codziennym” („Das Leben auf dem Land in der civitas Mattcorum", s. 50-65). Jest to najzwyklejsza kompilacja, w dodatku niezbyt wysokiego lotu. Autorka nic nowego tu nie wnosi, brakuje dyskusji chociażby nad wartością literatury czy źródłami literackimi (Pliniusz Starszy, Tacyt; Marcjalis). Pojawiają się potknięcia: w wykazie literatury brakuje Baatz 2002 (zob. s. 23, przypis 22, 23), 100 ha to oczywiście milion metrów kwadratowych, nie tysiąc (s. 51), podrozdział $1.3 \mathrm{w}$ spisie treści nosi tytuł "Siedlungsstruktur in der civitas Mattiacorum”, w tekście jednak (s. 51) przybrał brzmienie "Siedlungsschemata in der civitas Mattiacorum", etc.

Niezależnie od tego część druga, czyli katalog, przesądza o wartości merytorycznej pracy jako całości. Każdy badacz, który zajmuje się prowincjami rzymskimi, nie tylko tymi leżącymi nad Renem, na pewno po niego sięgnie. 